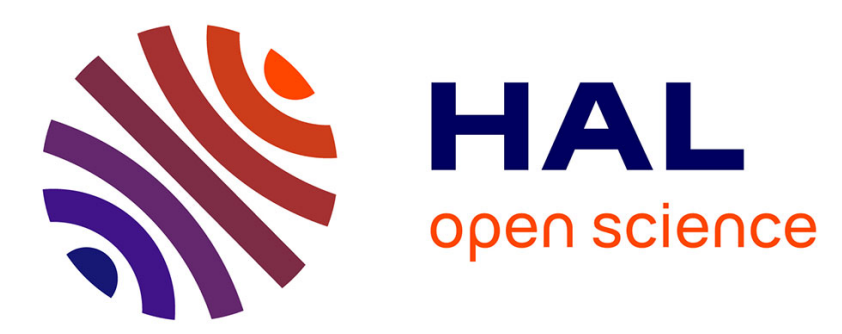

\title{
Physical and electrical properties of In2O3: Sn films. Applications to optoelectronic devices
}

\author{
J.-F. Bresse, J.-C. Manifacier
}

\section{To cite this version:}

J.-F. Bresse, J.-C. Manifacier. Physical and electrical properties of In2O3: Sn films. Applications to optoelectronic devices. Revue de Physique Appliquée, 1978, 13 (12), pp.757-760. 10.1051/rphysap:019780013012075700 . jpa-00244541

\section{HAL Id: jpa-00244541 https://hal.science/jpa-00244541}

Submitted on 1 Jan 1978

HAL is a multi-disciplinary open access archive for the deposit and dissemination of scientific research documents, whether they are published or not. The documents may come from teaching and research institutions in France or abroad, or from public or private research centers.
L'archive ouverte pluridisciplinaire HAL, est destinée au dépôt et à la diffusion de documents scientifiques de niveau recherche, publiés ou non, émanant des établissements d'enseignement et de recherche français ou étrangers, des laboratoires publics ou privés. 


\title{
PHYSICAL AND ELECTRICAL PROPERTIES OF $\operatorname{In}_{2} \mathrm{O}_{3}:$ Sn FILMS. APPLICATIONS TO OPTOELECTRONIC DEVICES
}

\author{
J. F. BRESSE and J. C. MANIFACIER
}

Laboratoire de Microscopie Electronique, Laboratoire de Physique des Solides III, U.S.T.L., pl. E.-Bataillon, 34060 Montpellier Cedex, France

\begin{abstract}
Résumé. - Des dépôts conducteurs et transparents d'oxyde d'indium dopé à l'étain $\left(\mathrm{In}_{2} \mathrm{O}_{3}: \mathrm{Sn}\right)$ préparés par une simple méthode spray ont été caractérisés.

Les concentrations de dopants ont été déterminées par une méthode de microanalyse $\mathrm{X}$ adaptée, et comparées avec les concentrations dans la solution.

Les propriétés électriqués ont été reliées aux résultats physiques de façon à contrôler le processus de fabrication en vue d'applications optoélectroniques.

Abstract. - Transparent highly conductive layers of tin doped indium oxide, $\operatorname{In}_{2} \mathrm{O}_{3}$ : Sn, prepared by a simple spraying method have been characterized. Stoichiometry and dopant concentrations of the layers, determined by an adapted method of X-ray microanalysis have been compared with concentrations in the solution. Electrical properties are related to the physical results in order to control the process for optoelectronic applications.
\end{abstract}

1. Introduction. - Recent interest in the fabrication of Schottky or heterojunction (H.T.J.) diodes is directly motivated by the greater facility of preparation, a lower cost than $\mathrm{p}-\mathrm{n}^{+}$Silicon junction diodes.

Prepared using a vapor transport method (spray), tin-oxide $\left(\mathrm{SnO}_{2}\right)$ and indium oxide $\left(\mathrm{In}_{2} \mathrm{O}_{3}\right)$ with dopant in thin layers are degenerate semi-conductors n-type $\left(n=10^{20}\right.$ to $\left.10^{21} \mathrm{~cm}^{-3}\right)$ and have a high transparency across the visible to near infrared (IR) spectrum [1]. They can be used as transparent and protective electrodes in the fabrication of solar cell structures Moreover, they could be used on polycristalline silicon substrates in future technology (due to the lowtemperature processing). They have also a high reflectivity in the I.R. So they can be used in flat plate collectors technology as spectral selective windows with large transmission for solar radiation and high reflection for thermal I.R. thus increasing the efficiency of the black-body collector.

We present here results concerning thin films of $\operatorname{In}_{2} \mathrm{O}_{3}$ with tin dopant on glass and silicon substrates.

2. Thin films experimental preparation. - As reported elsewhere [2], an aerosol stream containing an alcoholic solution of $\mathrm{SnCl}_{4}$ or $\mathrm{InCl}_{3}$ and an additional dopant is sprayed through a preheating furnace onto a heated substrate. The method of hydrolisis is based on the reversible endothermic reaction

$$
2 \mathrm{InCl}_{3}+2 \mathrm{H}_{2} \mathrm{O} \leftrightharpoons \mathrm{In}_{2} \mathrm{O}_{3}+6 \mathrm{HCl}
$$

which appears at $350^{\circ} \mathrm{C}$. The best results have been obtained for doping by adding stannic chlorine hydrated $\left(\mathrm{SnCl}_{4}, 5 \mathrm{H}_{2} \mathrm{O}\right)$.
A gas flow (nitrogen) is used as a carrier with a typical rate of about $31 / \mathrm{min}$. The deposition rate can vary from $2000 \AA$ to $4000 \AA / \mathrm{min}$. The typical layer thickness is $2000 \AA$ on a heated substrate at $500{ }^{\circ} \mathrm{C}$.

The value of the transparency (up to $85 \%$ ) can be easily optimized. The $R_{\mathrm{a}}$ value is reported on the figure 1 as function of the atomic ratio $\mathrm{Sn} / \mathrm{In}$ in the solution (for a preheating furnace temperature $T_{1}$ and

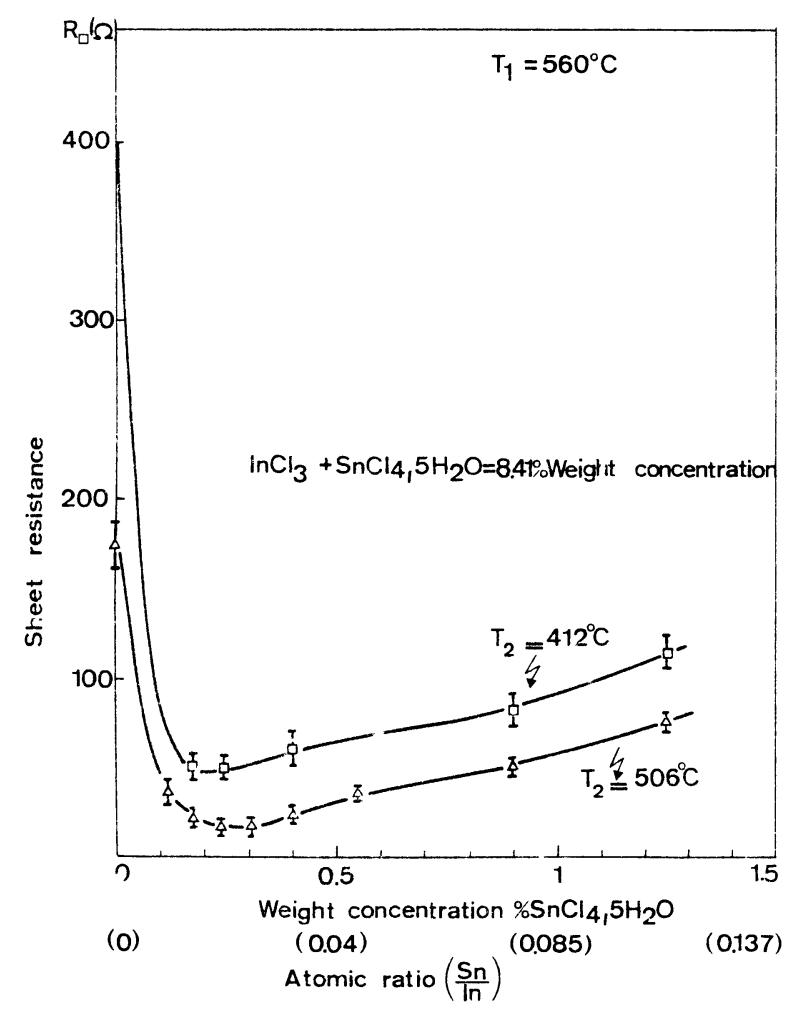

FIG. 1. - Sheet resistance $R_{\square}$ versus $\mathrm{SnCl}_{4}, 5 \mathrm{H}_{2} \mathrm{O}$ weight concentration. The $\mathrm{Sn} / \mathrm{In}$ atomic ratio is also indicated. 
two different substrate temperatures $T_{2}$ ). Moreover, parameters such as substrate temperature during deposition or $\mathrm{Sn} / \mathrm{In}$ atomic ratio in the layers can be of critical importance for the open circuit voltage $V_{\text {oc }}$ of the solar cell. It has been shown recently [3] that conversion efficiency around $10 \%$ for $\mathrm{Si}(\mathrm{n})-\mathrm{In}_{2} \mathrm{O}_{3}: \mathrm{Sn}$ structures under AM1 illumination can be obtained with lower substrate temperature $\left(430-450^{\circ} \mathrm{C}\right)$ and higher $\mathrm{Sn} / \mathrm{In}$ atomic ratio than the ones corresponding to the minimum sheet resistance reported on the figure 1 . So, the knowledge of $\mathrm{Sn} / \mathrm{In}$ atomic ratio is needed for these applications.

3. Characterization of the films. - As needed for a better knowledge of layer composition, quantitative dosimetry (element In, Sn, Cl, O) have been performed using an X-ray microanalyser. Qualitative analysis have been made using secondary ion mass spectroscopy (S.I.M.S.) in order to obtain ion mass spectrum and concentration profiles in the layer depth.

3.1 S.I.M.S. MEASUREMENTS. - A positive ion mass spectrum is shown in figure 2 for a film deposited on borosilicate glass slide. Many impurities appear in this spectrum $(\mathrm{K}, \mathrm{Na}, \mathrm{Si}, \mathrm{Al}, \mathrm{B}, \mathrm{Cl}, \mathrm{F})$.

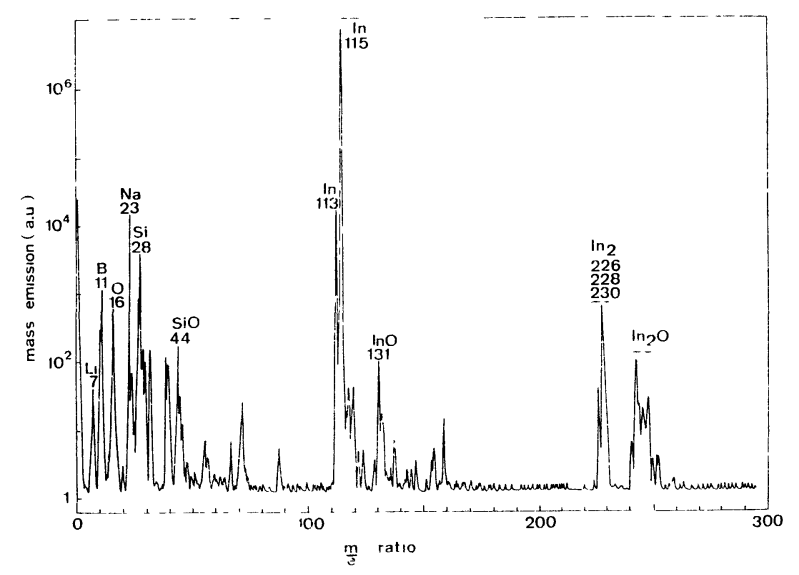

FIG. 2. - Dynamic positive secondary ion mass spectrum on an $\mathrm{In}_{2} \mathrm{O}_{3}$ : Sn layer (Borosilicate glass substrate).

An example of profiling by S.I.M.S. for the same $\mathrm{In}_{2} \mathrm{O}_{3}: \mathrm{Sn}$ layer obtained by monitoring the intensity of appropriate masses, for a large area under continuous ion bombardement is shown in figure 3 .

The accumulation at the interface of alkali ions and silicon can be noted, the borosilicate glass acting as a diffusion source for these elements.

The profiles show that the concentrations of major elements in the film (In, $\mathrm{Sn}, \mathrm{O})$ are practically constant.

3.2 EleCtron PRobe microanalysis. - Quantitative dosimetry have been made on many thin layers of $\operatorname{In}_{2} \mathrm{O}_{3}$ : Sn which thickness varies from $1000 \AA$ to $4000 \AA$.

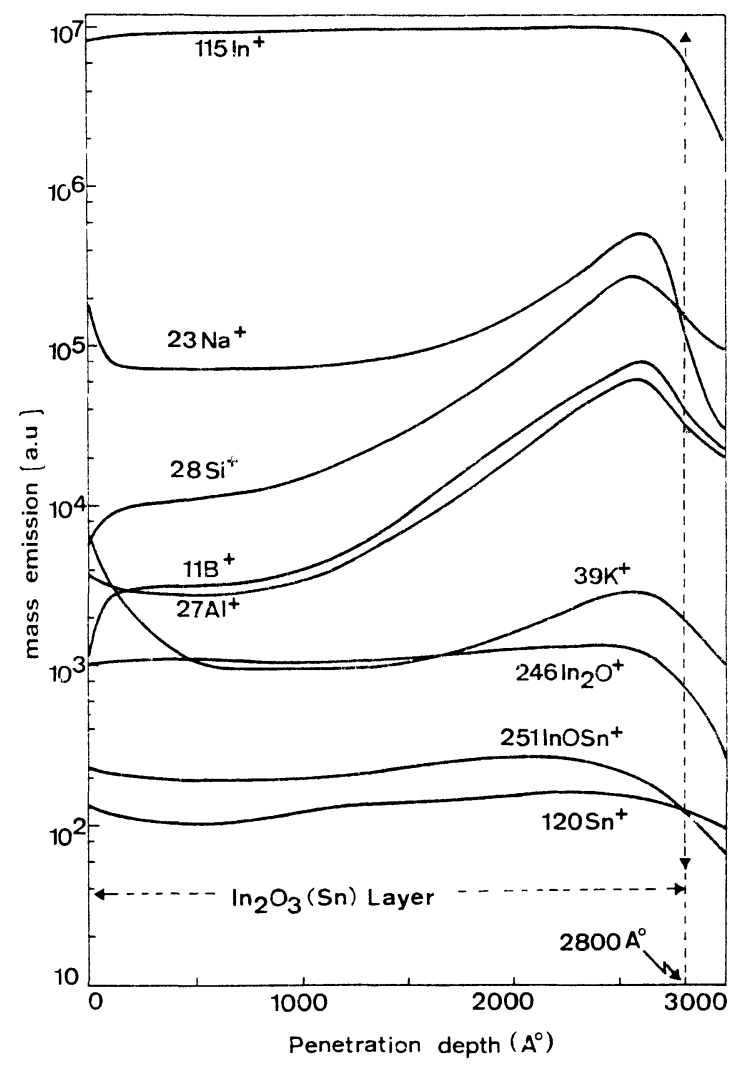

Fig. 3. - Depth profiling for an $\operatorname{In}_{2} \mathrm{O}_{3}$ : Sn layer. Positive ion mass spectra (Borosilicate glass substrate).

The quantitative use of X-ray microanalysis on thin films involves specific problems, that we try to solve by an appropriate solution [4]. We essentially take into account :

- of the electron penetration larger than the layer thickness,

- of the mean energy of electrons passing through the layer, which is bigger than the excitation energy of the characteristic emission of the elements being in the layer,

- of the mean energy of the backscattered electrons coming from the substrate.

A conventional method for corrections can be adapted to this new situation, only the measurements corresponding to an element present in the substrate (silicon in our case) and eventually the layer thickness are needed.

All the measurements need a standard for each analysed element and assume that the concentration of the elements determined by the analysis are constant in depth.

The concentration of the elements $\mathrm{Sn}, \mathrm{In}, \mathrm{Cl}$ have been tested to be constant in depth by S.I.M.S. profiles and are determined on a CAMECA microprobe using compound standards, oxygen have been determined by difference.

The stoichiometry and the atomic ratio $\mathrm{Sn} / \mathrm{In}$ and $\mathrm{Cl} / \mathrm{In}$ can be determined with an accuracy better than $5 \%$. Some examples of physical and electrical results are reported on the table I. 
TABLE I

$\begin{array}{cccccccc}\text { Sample } & \begin{array}{c}n \\ \mathrm{~cm}^{-3}\end{array} & \begin{array}{c}\rho \\ 10^{-4} \Omega \mathrm{cm}\end{array} & \begin{array}{c}\frac{\mathrm{Cl}}{\mathrm{In}} \\ \text { Solution }\end{array} & \begin{array}{c}\frac{\mathrm{Cl}}{\mathrm{In}} \\ \text { layer }\end{array} & \begin{array}{c}\frac{\mathrm{Sn}}{\mathrm{In}} \\ \text { Solution }\end{array} & \begin{array}{c}\frac{\mathrm{Sn}}{\mathrm{In}} \\ \text { layer }\end{array} & \begin{array}{c}\text { Thickness } \\ (\AA)\end{array} \\ - & - & - & - & - & - & - & - \\ 412 & 7.8 \times 10^{19} & 26.6 & 14.0 & 0.006 & 0.0 & 0.001 & 1400 \\ 415 & 3.2 \times 10^{20} & 7.6 & 14.0 & 0.0336 & 0.0045 & 0.007 & 1600 \\ 434 & 7.4 \times 10^{20} & 5.2 & 14.5 & 0.009 & 0.023 & 0.040 & 4800 \\ 224 & 4.2 \times 10^{20} & 14.8 & 15.6 & 0.0085 & 0.076 & 0.20 & 2000 \\ 527 & 5.2 \times 10^{20} & 11.2 & 16.2 & 0.0175 & 0.105 & 0.159 & 2700 \\ 525 & 4.1 \times 10^{20} & 51.6 & 19.4 & 0.025 & 0.25 & 0.26 & 1220\end{array}$

The Sn/In atomic ratio have been compared for the initial solution and the deposited layers, for the two types of substrates. The figure 4 reports the results obtained on borosilicate glass and the figure 5 compares some results obtained on glass and silicon substrates. Using this two curves, a linear relation can be established which corresponds to a slope of 1.6, so a more important quantity of the dopant exists in the layer than in the solution.

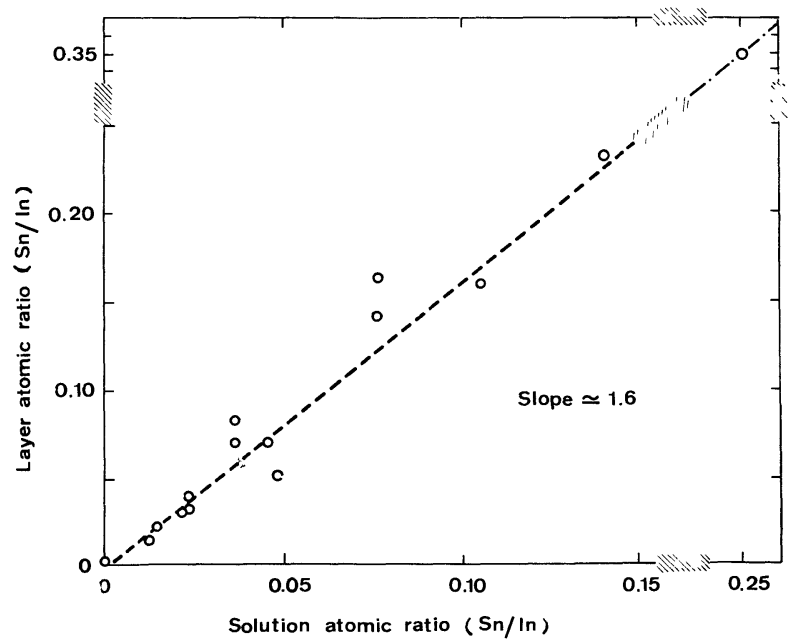

FIG. 4. - Sn/In atomic ratio in the $\operatorname{In}_{2} \mathrm{O}_{3}:$ Sn layers versus $\mathrm{Sn} / \mathrm{In}$ atomic ratio in the solution determined by $\mathrm{X}$-ray microanalysis (Borosilicate glass substrate).

Such a curve can be plotted for the chlorine quantity. The figure 6 represents the atomic $\mathrm{Cl} / \mathrm{In}$ ratio versus $\mathrm{Sn} / \mathrm{In}$ atomic ratio, where a linear variation can be also investigated. The initial chlorine concentration (for $\mathrm{Sn} / \mathrm{In}=0$ ) is still important, due to the presence of $\mathrm{InCl}_{3}$ and $\mathrm{HCl}$ in the solution.

4. Electrical properties. - Hall measurements permit the determination of the value of the carrier concentration $n$ and the mobility $\mu_{\mathrm{H}}$. The properties of some typical films with the lowest sheet resistance and highest optical transparency are listed in the table I. A free electron density of $n \simeq 10^{21} \mathrm{~cm}^{-3}$ can

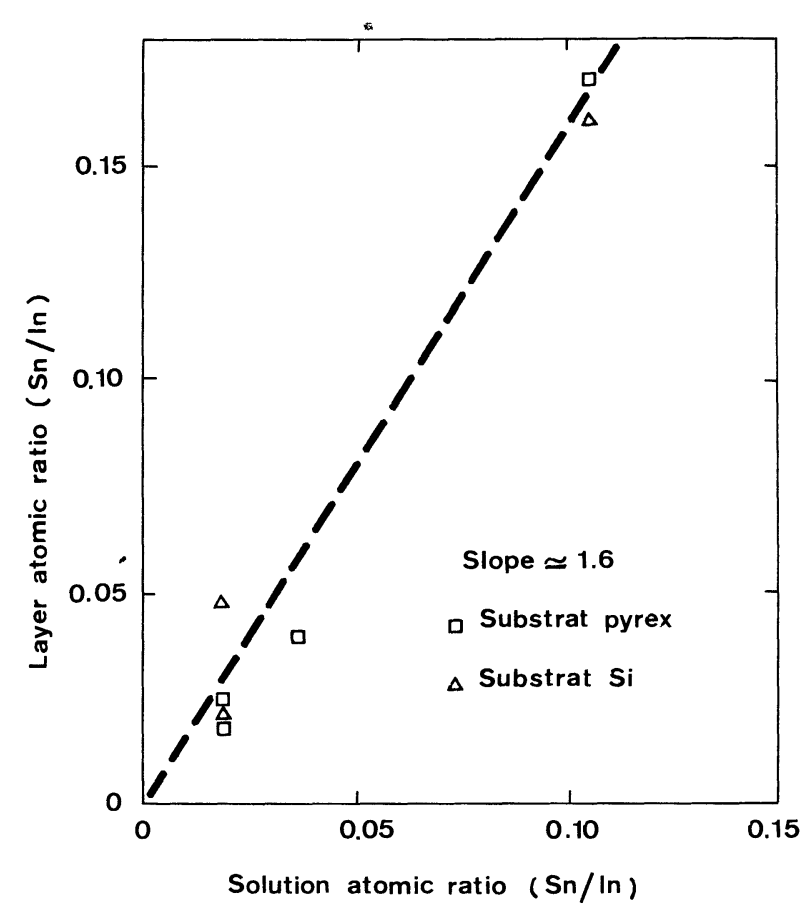

FIG. 5. - $\mathrm{Sn} / \mathrm{In}$ atomic ratio in layers versus $\mathrm{Sn} / \mathrm{In}$ atomic ratio in the solution for pyrex and silicon substrates.

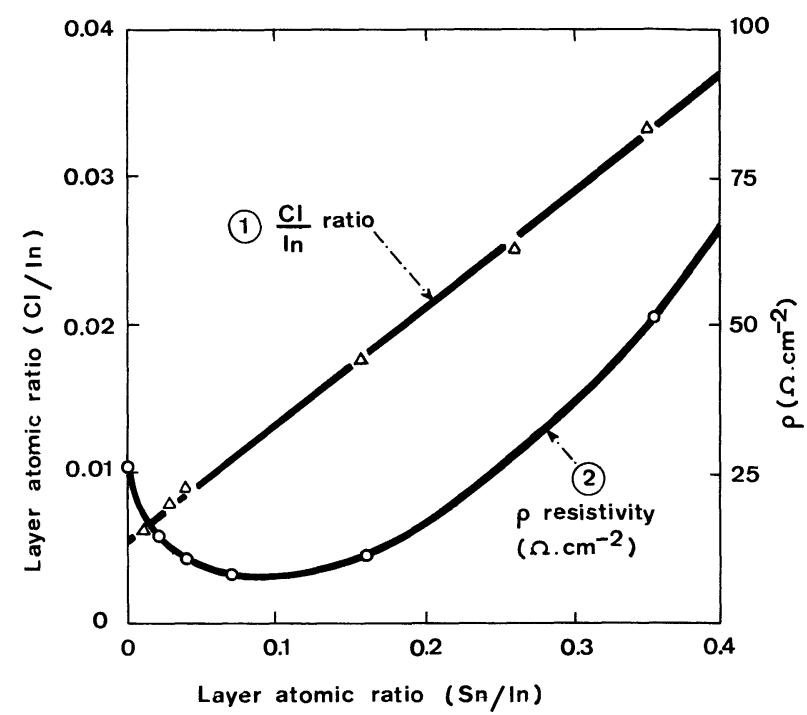

FIG. 6. $-\mathrm{Cl} / \mathrm{In}$ atomic ratio and resistivity of the layers versus atomic ratio $\mathrm{Sn} / \mathrm{In}$ in the solution. 
be achieved corresponding to a strongly degenerate semi-conductor.

The variation of the resistivity as function of the atomic ratio $\mathrm{Sn} / \mathrm{In}$ is also plotted on the figure 6 .

A maximum is observed in the carrier concentration, which corresponds to a minimum of the resistivity, for an atomic ratio $\mathrm{Sn} / \mathrm{In}=0.04$ in the layer.

The contribution to the conductivity of the ionized donors and the stoichiometry deviation has to be taken into account to explain the variation of the free carrier density with $\mathrm{Sn} / \mathrm{In}$. The heat treatment results are in good accordance with this analysis. After annealing under inert ambient (Ar) a decrease in the sheet resistance is observed even for highly doped samples corresponding to the creation of oxygen vacancies [5].

The difference in crystalline quality according to the various methods of preparation could easily explain the scattering in the $\mathrm{Sn} / \mathrm{In}$ atomic ratio found to give the lower resistivity films.
5. Conclusion. - $\operatorname{In}_{2} \mathrm{O}_{3}$ : Sn layers prepared using a very simple and cheep spray method have been characterized from the point of view of physical and electrical properties. In spite of a certain spread in the results, a good correlation can be obtained between electrical properties and the physical parameters, as dopant concentration determined by X-ray microanalysis and S.I.M.S. The choice of good experimental conditions of fabrications would permit to optimize the optical and the electrical properties.

These layers which have figure of merit of the same order of magnitude than those obtained by the best deposition technique, can be made easily with a high production rate necessary to industrial applications. They have also a good adherence and stability.

Acknowledgements. - We thank R. Stück (C.R.N. Strasbourg) for S.I.M.S. measurements.

\section{References}

[1] Manifacier, J. C., Wadi, K., Bresse, J.-F., SAvelli, M., I Colloqui International d'energia solar, Barcelona Spain (1977).

[2] Manifacier, J. C., De Murcia, M., Fillard, J.-P., Mat. Res. Bull. 10 (1975) 1215.

[3] Manifacier, J. C., Szepessy, L., Appl. Phys. Lett. 31 (1977) 459.
[4] Bresse, J.-F., Manifacier, J. C., Colloque Couches Minces, Les Arcs (1978), Le Vide 189 (1978) 73.

[5] Manifacier, J. C., Szepessy, L., Bresse, J.-F., Stuck, R., Mat. Res. Bull. (to be published). 